\title{
REINTERPRETASI KATA JILBAB DAN KHIMAR DALAM AL-QURAN; PENDEKATAN MA'NA CUM MAGHZA SAHIRON SYAMSUDDIN
}

\author{
Siti Robikah ${ }^{1}$
}

\begin{abstract}
Abstrak:
Aurat perempuan banyak diperdebatkan oleh beberapa kalangan baik tentang batasan aurat itu sendiri ataupun batas penutupnya. Al-Quran menjelaskan penutup aurat bagi perempuan dalam ayat dan surah yang berbeda. Dalam QS. an-Nur [24]: 31, al-Quran menjelaskan mengenai perintah menutupkan kain kerudung ke dadanya. Dalam ayat ini menggunakan kata "khimar" sebagai sebuah kain yang menutup aurat perempuan. Namun berbeda dengan QS. al-Ahzab [33]: 59 yang memerintah perempuan untuk menutup aurat dengan kata "jilbab". Dalam ayat ini Allah memerintahkan perempuan untuk menutupkan jilbabnya ke seluruh tubuh perempuan. Maka dari itu, sebenarnya ada perbedaan antara penggunaan kata "jilbab" dan "khimar". Dengan menggunakan pendekatan ma'na cum maghza Sahiron Syamsuddin, artikel ini akan membahas mengenai kata "khimar" dan "jilbab" dimana keduanya digunakan dalam ayat yang menjelaskan tentang aurat perempuan. Pendekatan Ma'na-cum-maghza merupakan pendekatan dalam penafsiran yang menjadikan makna asal literal (makna historis, tersurat) sebagai pijakan awal untuk memahami pesan utama teks (makna yang tersirat). Pendekatan ma'na-cum-maghza terdiri dari makna (ma'na) suatu teks al-Quran yang dipahami oleh pendengar pertama dan dikembangkan menjadi signifikansi (maghza) untuk situasi kontemporer. Maka dari itu, kata "khimar" dan "jilbab" akan ditemukan perbedaan dan makna yang tersirat dari keduanya. Karena diketahui bahwa kedua kata tersebut sekarang ini dimaknai sama, yang akhirnya menyebabkan adanya legitimasi teologis kewajiban pemakaian jilbab sebagai penutup aurat perempuan secara keseluruhan.
\end{abstract}

Kata kunci: Perempuan, Jilbab, Khimar, Ma'na cum maghza.

\section{PENDAHULUAN}

Permasalahan diwajibkannya penggunaan jilbab bagi perempuan tidak berhenti pada satu kesepakatan. Pembahasan mengenai masalah ini sampai pada permasalahan aurat perempuan. masalah aurat perempuan juga menimbulkan banyak perbedaan pendapat. Khususnya pada batas-batas yang diperbolehkan kaum perempuan untuk memperlihatkan anggota tubuhnya. Banyak ulama yang mengatakan bahwa seluruh bagian tubuh perempuan adalah aurat namun juga beberapa lainnya mengatakan bahwa aurat perempuan kecuali wajah dan telapak tangan. $^{2}$

Kewajiban pemakaian jilbab oleh para muslimah selalu dikaitkan dengan QS. an- Nur: 31 dan al-Ahzab: 59. Ayat ini menjelaskan mengenai perintah menutup aurat dengan menjulurkan kain kerudung di dadanya. Ayat ini diturunkan ketika dari Ibnu Abi Hatim meriwayatkan dari Muqatil, dari Jabir bin Abdillah, menceritakan bahwa Asma binti Marthad ketika itu sedang berada di kebun kurmanya. Beberapa wanita kemudian masuk ke kebunnya tanpa mengenakan

\footnotetext{
${ }^{1}$ Universitas Islam Negeri Sunan Kalijaga Yogyakarta, Email: bikarobikah@gmail.com

2 Safitri Yulaikhah, "Jilbab Antara Kesalehan Dan Fenomena Sosial," Jurnal Ilmu Dakwah Vol. 36 No (2016): 97.
} 
busana sehingga terlihat gelang kaki mereka,juga terlihat dada dan rambut mereka. Maka Asma' berkata, "Alangkah buruknya hal ini!" maka Allah menurunkan ayat tersebut. ${ }^{3}$ Ayat ini kemudian menjadi awal perdebatan aurat perempuan dan pemaknaan penutup auratnya.

Ayat lain juga diklaim sebagai perintah untuk perempuan muslimah menutup auratnya. QS. al-Ahzab: 59. Hai Nabi, katakanlah kepada isteri-isterimu, anak-anak perempuanmu dan isteri-isteri orang mukmin: "Hendaklah mereka mengulurkan jilbabnya ke seluruh tubuh mereka". Yang demikian itu supaya mereka lebih mudah untuk dikenal, karena itu mereka tidak di ganggu. Dan Allah adalah Maha Pengampun lagi Maha Penyayang. Ayat ini diturunkan kepada wanita-wanita Madinah pada zaman dahulu yang keluar di malam hari untuk buang air besar. Saat itu orang-orang fasiq juga keluar rumah. Ketika mereka melihat wanita menggunakan cadar, berkata mereka "Dia perempuan merdeka", maka kemudian mereka meninggalkannya. Jika mereka melihat wanita yang tidak bercadar, mereka akan berkata "Dia adalah budak", mereka lalu menagkapnya. Kemudain turunlah ayat ini. ${ }^{4}$ Berdasarkan asbaab alnuzul ini kemudian beberapa kelompok berpendapat bahwa kewajiban menutup aurat perempuan termasuk cadar agar tidak mendapat gangguan dari orang-orang fasi seperti ketika itu.

Perdebatan aurat dan pemakaian jilbab memang belum dapat dituntaskan secara sempurna. Jika melihat dari kedua ayat tersebut, sebenarnya tidak kemudian dapat dijadikan patokan secara menyeluruh. Tulisan ini penting untuk melihat bagaimana sebenarnya makna jilbab dan khimar dalam kedua ayat tersebut agar tidak terjadi kesalahpahaman yang menyebabkan adanya klaim kebenaran dalam hal menutup aurat. Dengan menggunakan ma'na cum maghza, tulisan ini akan mencoba menelusuri makna tersirat dari dua kata tersebut.

Banyak artikel ataupun tulisan yang menjelaskan mengenai pemaknaan jilbab sebelum ini. Artikel yang ditulis oleh Safitri Yulaikhah dengan judul Jilbab antara Kesalehan dan Fenomena Sosial yang dipublikasikan oleh jurnal ilmu dakwah tahun 2016. Dalam artikel ini penulis menjelaskan bahwa jilbab merupakan produk budaya yang diperkuat dengan anjuran agama dengan alasan perlindungan atau kemaslahatan, namun dalam hal kereligiusan atas hijab penulis tidaklah menyetujuinya. Tidak ada jaminan orang yang memakai jilbab adalah orang yang salehah dan tidak sebaliknya bahwa orang yang tidak menggunakan jilbab adalah orag yang tidak salehah. Jilbab hanyalah peningkay dari ekspresi dan simbol feminitas. Yang ditekankan dalam perintah Allah bukanlah pemakaian jilbab namun pergaulan dan tingkah laku yang baik kepada sesama manusia. ${ }^{5}$

3 Jalaluddin Al-Suyuti, Lubab Al-Nuqul Fi Asbab Al-Nuzul (Beirut: Muassasat al-Kutub alTsaqafiyyah, 2002), 187.

4 Al Wahidi, Asbab Al-Nuzul (Beirut: Dar al-Kutub, 1991), 377.

5 Yulaikhah, "Jilbab Antara Kesalehan Dan Fenomena Sosial," 96-117. 
Artkel dalam jurnal Masyarakat jurnal sosiologi dengan judul Jilbab Sebagai Representasu Simbolik Mahasiswa Muslim di Universitas Indonesia. dalam junal ini menjelaskan mengenai penggunaan jilbab yang tidak hanya komitmen teologis saja namun juga adanya komitme terhadap kelompok yang dimanifestasikan melalui simbol jilbab yang mereka gunakan sesuai dengan konstruksi dari pemilik otoritas agama yang terlegitimasi secara sosial. Komitmen dalam kelompok ini diejawantahkan melalui konformitas yang dilakukan individu agar mendapatkan ruang untuk berpartisipasi lebih jauh dalam kelompok yang dituju. ${ }^{6}$

Adapun artikel yang membahas tentang ma'na cum maghza belum terlalu banyak. Seperti Artikel dengan judul Dinamika dan Terapan Metodologi Tafsir Kontekstual (Kajian Hermeneutika Ma'na-cum-Maghza terhadap penafsiran QS. Al$\left.M a^{\prime} u n / 107\right)$. Artikel ini dipublikasikan oleh Jurnal Al-Izzah: Hasil-Hasil penelitian vol.14, No.1, Mei 2019. Surah Al-Ma'un/107 oleh mufasir klasik masih cenderung memaknai sebagai ayat-ayat normatif dan masih stagnan pada ruang lingkup pembahasannya yang dipengaruhi oleh kondisi problematika sosial yang dihadapi oleh umat Islam pada masa pewahyuan,sehingga nampak kaku ketika diterapkan pada zaman kekinian, terlebih untuk menghadapi tantangan di era revolusi industri 0.4 .

Dengan menggunakan penafsiran hermeneutika ma'na-cum-maghza yang mampu melahirkan makna kontekstual, dapat dipahami bahwa kandungan QS. AlMa'un/107 adalah (1) ajaran agama yang mencakup urusan spiritual dan sosial; (2) kepedulian sosial tidak hanya terbatas kepada anak yatim dan orang-orang miskin, melainkan semua jenis ketertindasan terhadap nilai-nilai kemanusiaan di setiap zaman; (3) ajaran keberagamaan khususnya agama Islam tidak hanya mementingkan urusan simbolitas religius, dan praktik spiritual Agama, melainkan juga membutuhkan implementasi sosial sebagai manifestasi dari nilai-nilai ajaran rahmatan lil 'alamin; (4) praktik ajaran agama bukan untuk dipertontonkan, disombongkan, apalagi untuk mendapatkan pujian duniawi, melainkan demi mewujudkan ketaatan kepada Allah swt., sebagai bentuk pengabdian hamba; (5) nilai utama dari perintah shalat, bukan hanya pada pelaksanaan secara teknis, melainkan nilai-nilai spritual dan sosial dalam shalat dapat diaplikasikan dalam kehidupan sosial kemasyarakatan. ${ }^{7}$

M. Dani Habibi dalam artikel yang dipubikasikan oleh jurnal al-Dzikra Vol.13, No.1 Juni 2019 dengan judul Penafsiran Dalil Radikalisme dan Terorisme di Indonesia (Interpretasi Ma'na-cum-Maghza Terhadap Kata Fitnah dalam al-Quran Surat al-Baqarah: 190-193). Al-Qur'an surat al-Baqarah: 190-93 adalah merupakan ayat yang berkaitan

${ }^{6}$ Eveline Ramadhani, “Jilbab Sebagai Representasi Simbolik Mahasiswi Muslim Di Universitas Indonesia," Masyarakat Jurnal Sosiologi Vol. 27 No (2017): 81-103.

7 Abdul Muiz Amir, "Dinamika Dan Terapan Metodologi Tafsir Kontekstual (Kajian Hermenutika Ma'na-Cum-Maghza Terhadap Penafsiran QS Al-Ma'un/107)," Al Izzah: Jurnal HasilHasil Penelitian Vol. 14 No (2019): 1-17. 
tentang diplomasi bukan dalil tentang peperangan yang dipahami oleh Imam Samudra, Noordin M. Top dan Ali Imron. Penulis menggarisbahawi bahwa pemahaman yang dilakukan oleh oknum teroris tersebut adalah salah dan perlu dikaji ulang ayat-ayat yang menjadi dasar gerakan teroris tersebut. Supaya tidak menyebarkan fitnah dimanapun berada. Dan dapat diyakini, mereka kaum teroris adalah umat Islam yang salah ketika memahami al-Qur'an. Oleh karenanya, perlu interpretasi lebih mendalam supaya bisa didapatkan ide moral atau pesan moral yang kontekstual. QS. Al-Baqarah: 190-193. Ide moral dalam QS. Al-Baqarah: 190-193 adalah berisi tentang etika dalam berdiplomasi seperti kejujuran dalam berdiplomasi kesepakan bersama tanpa ada pelanggaran satubelahpihak dan menjunjung tinggi perdamaian. Bukan justru memunculkan permusuhan, perpecahan dan ancaman kepada orang lain yang pada akhirnya merugikan bahkan menimbulkan korban jiwa seperti peristiwa yang dilakukan oleh oknum teroris dalam peristiwa bom Bali.

\section{PEMBAHASAN}

\section{Ma'na cum maghza Sahiron Syamsuddin}

Sahiron syamsuddin dilahirkan di Cirebon pada tanggal 11 Agustus 1968. riwayat pendidikan dimulai dari meempuh ilmu di Pondok pesantren Raudhatu alThalibin (1981-1987) Babakan Ciwaringin Cirebon sekaligus menempuh pendidikan formal pada Madrasah Tsanawiyah dan Madrasah Aliyah ditepat yang sama. Selain itu, beliau juga belajr ilmu agama di pondok pesantren Nurussalam. Pendidikan formal beliau dilanjutkan di IAIN Sunan Kalijaga Yogyakarta dengan mengambil jurusan Tafsir Hadis (1987-1993). ${ }^{8}$ Tidak sampai disitu, beliau kemudian melanjutkan perjalanan keilmuannya di McGill University, Kanada tentang kajian Islam serta menempuh pendidikan dalam bidang kajian Islam, Orientalisme, Filsafat Arab dan Sastra Arab di Bamberg University dan berhasil meraih gelar doktor pada tahun 2006. Sahiron Syamsuddin tercatat sebagai dosen di fakultas ushuludin dan pemikiran Islam dan pascasarjana UIN Sunan Kalijaga Yogyakarta. Selain itu, beliau mendirikan pondok pesantren baitul hikmah dan aktif mengajar teks-teks klassik dan juga hermenutika Gracia. Beliau pun tercatat sebagai intelektual muslim yang produktif dalam menuangkan pemikirannya dalam tulisan sebagai bentuk kegelisahan akadaemik dan respon terhadap fenomena yang berkembang. ${ }^{9}$

8 Di IAIN Sunan Kalijaga Yogyakarta ini beliau mulai mempelajari tentang pemikiran tradisional dan modern serta mempelajari keilmuan Islam timur dan barat. Pijakan pemikiran inilah yang kemudian membuat beliau semakin tertarik untuk mempelajari tentang studi Islam serta keinginan mengkombinasikan antara keilmuan Islam tradisional yang telah ia peroleh di pondok pesantren dan keilmuan modern (Barat). Lihat Abdullah, "Metodologi Penafsiran Kontemporer (Telaah Pemikiran Sahiron Syamsuddin Tahun 1990-2013)" (Fakultas Ushuluddin dan Pemikiran Islam UIN Sunan Kalijaga Yogyakarta, 2013), 16.

${ }^{9}$ Adapun karya beliau diantaranya yakni pertama buku sekaligus tesis beliau yang berrjudul An Examination of Bint al-Shati' 's Method of Intrepeting the Qur'an, Die Koranhermenutik Muhammad Sahrurs und ihre Beurteilung aus der Sicht muslimischer Autoren: Eine Kritische untersuchung (2009), Tafsir Studies (2009), Hermenutika dan Pengembangan Ulumul Qur'an (2009). Adapun artikel yang 
Adapun tokoh yang berpengaruh dalam pemikirannya diantaranya yakni Hans Georg Gadamer dan Georg Gracia sebagai tokoh yang mempengaruhi pemikiran hermenutiknya, sedangkan tokoh-tokoh intelektual muslim seperti Fazlur Rahman (teori double movement), Nasr Hamid Abu Zayd (Analisa bahasa) dan Abdullah Saeed (penafsiran kontekstualis), beberapa nama tokoh tersebut mempengaruhi pemikiran beliau khusunya pada masalah penafsiran yang relevan untuk masa kini. Adapun Yudian Wahyudi juga turut mempengaruhi pemikiran beliau dalam hal kritis metodologis. ${ }^{10}$

Sahiron Syamsuddin membagi aliran hermeneutika dari segi pemaknaan terhadap obyek penafsiran menjadi tiga aliran, yaitu aliran objektivis, aliran subjektivis dan objektivis-cum-subjektivis. ${ }^{11}$ Dengan melihat kecenderungan dari adanya aliran-aliran hermeneutika umum tersebut, ia berpendapat bahwa di sana terdapat kemiripan dengan aliran dalam penafsiran al-Quran saat ini. Sehingga Sahiron membagai tipologi penafsiran al-Quran kontemporer menjadi tiga, yaitu pandangan quasi-objektvis tradisionalis, pandangan quasi-objektivis modernis dan pandangan subjektivis. ${ }^{12}$ Dari adanya ketiga tipologi tersebut, menurut Sahiron yang

dipublikasi di jurnal internasional di antaranya artikel yang berrjudul "Bint al-Shati' on Asbab alNuzul" (1998), Muhkam Mutasaybih: An Analytical Study of al-Thabari's and al-Zamakhshari Interpretation of Qs. 3: 7 (1999) an lain sebagainya. Lihat Abdullah, 18-22.

10 Abdullah, 23.

11 Pertama, aliran objektivis, yaitu aliran hermeneutika yang lebih menekankan pada pencarian makna asal dari obyek penafsiran (teks tertulis, teks diucapkan, perilaku, simbol-simbol kehidupan dll.). Jadi, penafsiran disini adalah upaya merekonstruksi apa yang dimaksud oleh pencipta teks. Di antara yang bisa digolongkan dalam aliran ini adalah Friedrich D. E. Schleirmacher dan Wiliam Dilthey. Kedua, aliran subjektivis, yakni aliran yang lebih menekankan pada peran para pembaca/penafsir dalam pemaknaan terhadap teks. Menurutnya, pemikiran-pemikiran dalam aliran ini terbagi menjadi tiga. Ada yang sangat subjektivis, yaitu 'dekonstruksi' dan reader-response critism. Ada yang agak subjektivis seperti post-strukturalisme dan ada yang kurang subjektivis, yakni strukturalisme. Adapun yang ketiga adalah aliran objektivis-cum-subjektivis, yakni aliran yang memberikan keseimbangan antara pencarian makna asal teks dan peran pembaca dalam penafsiran. Yang termasuk dalam aliran ini adalah Hans Georg Gadamer dan Jorge J.E. Gracia. Lihat Sahiron Syamsuddin, Hermeneutika Dan Pengembangan Ulumul Qur'an (Yogyakarta: Pesantren Nawesea Press, 2009), 26.

12 Pertama, pandangan quasi-objektivis tradisionalis, yaitu suatu pandangan bahwa ajaranajaran Al-Qur'an harus dipahami, ditafsirkan dan diaplikasikan pada masa sekarang, sebagaimana ia dipahami, ditafsirkan dan diaplikasikan pada situasi, di mana Al-Qur'an diturunkan kepada Nabi Muhammad SAW. dan disampaikan kepada generasi Muslim awal. Menurut Sahiron, bagi kelompok ini, esensi pesan Tuhan adalah yang tertera secara tersurat dan pesan itulah yang harus diaplikasikan di manapun dan kapanpun. Di antara yang tergolong kelompok ini, menurutnya, seperti Ikhwanul Muslimin dan kaum salafi. Kedua, pandangan quasi-objektivis modernis, yang memandang makna asal literal sebagai pijakan awal untuk memahami makna dibalik pesan literal yang merupakan pesan utama Al-Qur'an. Makna di balik pesan literal inilah yang menurut mereka harus diimplementasikan pada masa kini dan akan datang. Menurut Sahiron, contoh dari kelompok ini antara lain; Fazlur Rahman, Nasr Hamid Abu Zayd dan Muhammad al-Thalibi. Dan yang terakhir adalah pandangan subjektivis yang menegaskan bahwa setiap penafsiran sepenuhnya merupakan subjektivitas penafsir, sehingga kebenaran interpretatif itu bersifat relatif. Atas dasar ini, maka menurut kelompok ini, setiap generasi mempunyai hak untuk menafsirkan Al-Qur'an sesuai dengan perkembangan ilmu dan pengalaman pada saat Al-Qur'an ditafsirkan. Yang termasuk kelompok ini menurut Sahiron adalah Muhammad Syahrur. Lihat, Sahiron Syamsuddin, Hermeneutika dan Pengembangan Ulumul Qur'an, 
paling dapat diterima adalah pandangan quasi-objektivis modernis, sebab di sana terdapat "keseimbangan hermeneutika". Ia memberi perhatian yang sama terhadap makna asli literal (al-ma'na al-asli) dan pesan utama (signifikansi: maghza) ${ }^{13}$ di balik makna literal. Kemudian Sahiron mengistilahkannya dengan pembacaan ma'na-cummaghza.

Ma'na-cum-maghza merupakan penafsiran yang menjadikan makna asal literal (makna historis, tersurat) sebagai pijakan awal untuk memahami pesan utama teks (makna yang tersirat). ${ }^{14}$ Sesuatu yang dinamis dalam penafsiran bukanlah makna literal namun pemaknaan signifikansi atas teks dan historis-dinamis sepanjang peradaban manusia. Menurut Sahiron, pendekatan yang seperti ini merupakan pendekatan yang menggabungkan antara wawasan teks dan wawasan penafsir, antara masa lalu dan masa kini, dan antara aspek Ilahi dengan aspek manusiawi. Maka dari itu terdapat balanced hermeneutics dalam pendekatan ma'na-cum-maghza. ${ }^{15}$

Pendekatan ma'na-cum-maghza adalah pendekatan dalam penafsiran yang mana terdiri dari makna (ma'na) suatu teks al-Quran yang dipahami oleh pendengar pertama dan dikembangkan menjadi signifikansi (maghza) untuk situasi kontemporer. Ada beberapa metodologi yang hampir sama dengan pendekatan ini, menurut Sahiron. Fazlur Rahman yang menyebutnya dengan pendekatan double movement dan Abdullah Saeed yang mempekenalkan pendekatan kontekstual yang sama diaplikasikan dalam ayat-ayat hukum saja. Namun berbeda dengan ma'na-cummaghza yang mencoba mengapresiasikan seluruh pemaknaan al-Quran. ${ }^{16}$

h. 73-76. Lihat Sahiron Syamsuddin, “Tipologi Dan Proyeksi Penafsiran Kontemporer Terhadap AlQur'an," Al-Qur'an Dan Hadis Vol. 8 No. (2007): 198-200.

13 Menurut Sahiron, signifikansi terbagi menjadi dua yaitu; signifikansi fenomenal dan signifikansi ideal. Pertama, yang dimaksud dengan signifikansi fenomenal adalah pesan utama yang dipahami dan diaplikasikan secara kontekstual dan dinamis mulai pada masa Nabi saw. hingga saat ia ditafsirkan dalam periode tertentu. Ia terbagi menjadi dua, yaitu signifikansi fenomenal historis dan signifikansi fenomenal dinamis. Signifikansi fenomenal historis adalah pesan utama sebuah ayat atau kumpulan ayat yang dipahami dan diaplikasikan pada masa pewahyuan (masa Nabi saw). Sedangkan signifikansi fenomenal dinamis adalah pesan Al-Qur'an yang dipahami dan didefinisikan pada saat ayat atau kumpulan ayat tertentu ditafsirkan, dan setelah itu diaplikasikan dalam kehidupan. Untuk memahami signifikansi fenomenal historis, diperlukan pemahaman terhadap konteks makro dan mikro sosial keagamaan masyarakat yang hidup pada masa pewahyuan. Informasi-informasi historis yang terkandung dalam asba $>b$ al-nuzu $>1$ menjadi sangat penting. Sementara itu, untuk memahami signifikansi fenomenal dinamis, diperlukan pemahaman terhadap perkembangan pemikiran dan Zeitgeist (spirit masa/ zaman) pada saat penafsiran teks. Kedua, adapun yang dimaksud dengan signifikansi ideal adalah akumulasi ideal dari pemahamanpemahaman terhadap signifikansi ayat. Akumulasi ini akan diketahui pada akhir tujuan peradaban manusia yang dikehendaki oleh Allah Swt. Di sini, dapat diketahui bahwa sesuatu yang dinamis dari penafsiran, bukan terletak pada pemaknaan teks, melainkan pada pemaknaan terhadap signifikansi (pesan utama) teks. Lihat Syamsuddin, 106.

14 Syamsuddin, Hermeneutika Dan Pengembangan Ulumul Qur'an, 85.

${ }^{15}$ Syamsuddin, “Tipologi Dan Proyeksi Penafsiran Kontemporer Terhadap Al-Qur'an,” 202.

16 Sahiron Syamsuddin, "Ma'na-Cum-Maghza Approach to The Quran: Interpretation of Q. 5:51," Education and Humanities Research Vol. 137 (2017): 132. 
Secara garis besar langkah-langkah metodis konkretnya, pertama seorang penafsir menganalisa bahasa teks al-Quran. seorang penafsir harus memperhatikan bahwa bahasa yang digunakan dalam teks al-Quran adalah bahasa Arab abad ke-7 M. yang mempunyai karakter tersendiri baik dari segi kosa kata maupun struktur tata bahasanya. Untuk mempertajam analisa ini seorang penafsir harus melalakukan intratekstualitas dalam arti membandingkan dan menganalisa penggunaan kata yang sedang ditafsirkan. ${ }^{17}$ Asumsi pada setiap pendekatan teks, termasuk pada teks al-Quran, diawali dengan historical meaning yang spesifik pada konteks tersebut. Makna kebenaran al-Quran secara universal adalah proses menuju penafsiran selanjutnya. Proses ini mendasarkan pada fakta bahwa setiap bahasa begitu juga bahasa al-Quran memiliki aspek sinkronik dan diakronik. Aspek sinkronik dalam pemahaman linguistik tidak berubah, namun diakronik adalah yang dirubah dari waktu ke waktu. ${ }^{18}$

Kedua, penafsir memperhatikan konteks historis pewahyuan ayat-ayat al-Quran baik yang bersifat mikro ataupun yang bersifat makro. Konteks historis makro adalah konteks yang mencakup situasi dan kondisi bangsa Arab pada masa pewahyuan al-Quran. Sedangkan konteks mikro adalah konteks yang melatarbelakangi turunnya suatu ayat yang biasa disebut dengan asbaab al-nuzul.19 Ketiga, penafsir mencoba menggali maqshad atau maghza ayat yang sedang ditafsirkan. Hal ini dapat diketahui dengan memperhatikan konteks hostoris dan ekspresi bahasa al-Quran. simbol-simbol yang ada di kedua harus dipahami secara baik. Selanjutnya, penafsir mencoba mengkontekstualisasikan maghza al-ayat untuk konteks kekinian. ${ }^{20}$

Kata Jilbab dalam QS. al-Ahzab [33]: 59

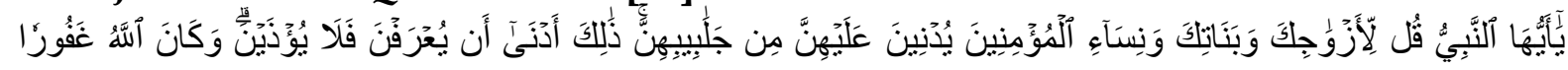
رََّحِيمًا

59. Hai Nabi, katakanlah kepada isteri-isterimu, anak-anak perempuanmu dan isteri-isteri orang mukmin: "Hendaklah mereka mengulurkan jilbabnya ke seluruh tubuh mereka". Yang demikian itu supaya mereka lebih mudah untuk dikenal, karena itu mereka tidak di ganggu. Dan Allah adalah Maha Pengampun lagi Maha Penyayang.

Seperti yang telah dijelaskan sebelumnya bahwa ayat ini diturunkan bukan berkaitan dengan aurat perempuan, tetapi lebih dari itu yakni agar mereka tidak diganggu oleh pria-pria yang tidak bertanggung jawab. Sebelum turunnya ayat ini, cara berpakaian wanita merdeka atau budak, yang baik ataupun tidak dikatakan hampir sama. Karena itu laki-laki yang tidak bertanggung jawab akan mengganggu wanita-wanita khususnya yang mereka duga sebagai seorang hamba sahaya. Untuk

\footnotetext{
17 Syamsuddin, Hermeneutika Dan Pengembangan Ulumul Qur'an, 142.

18 Syamsuddin, “Ma'na-Cum-Maghza Approach to The Quran: Interpretation of Q. 5:51,” 132.

19 Syamsuddin, Hermeneutika Dan Pengembangan Ulumul Qur'an, 142.

20 Syamsuddin, 142-43.
} 
membedakan wanita merdeka dan hamba sahaya akhirnya perintah menggunakan penutup atau memakai jilbab. ${ }^{21}$

Surah al-Ahzab [33]: 59, memerintahkan kaum perempuan mukmin mengulurkan jilbab. Muhammad Thahir Ibnu Asyur mengatakan bahwa ajaran ini dipertimbangkan untuk orang-orang Arab yang mempunyai adat berjilbab, maka dari itu kewajiban ini tidak akan berlaku bagi adat yang tidak menjadikan jilbab sebagai adat mereka. Dalam al-Qurnan maupun hadis tidak pernah menyinggung bentuk pakaian secara khusus. Nasaruddin Umar menjelaskan bahwa dalam bukunya Ketika Fikih Membela Perempuan, al-Quran dan hadis tidak pernah menyinggung bentuk pakaian secara khusus. Ada dua istilah populer dalam alQuran untuk pakaian penutup kepala, yaitu khumur dan jalabih. Keduanya dalam bentuk jamak dan bersifat generik. Kata khumur (QS. an-Nur [34]: 31), bentuk jamak dari khimar dan kata jalabih (QS. al-Ahzab [33]: 59) bentuk jamak dari kata jilbab. Jilbab berasal dari kata jalaba berarti menghimpun dan membawa. Jilbab pada masa Nabi ialah pakaian luar yang menutupi segenap anggota badan dari kepala hingga kaki perempuan dewasa. Jilbab dalam arti penutup kepala hanya dikenal di Indonesia. ${ }^{22}$

Tadisi jilbab sebenarnya bukan tradisi orisinil bangsa Arab, bukan pula tradisi Talmud dan Bibel. Tokoh penting dalam Bibel seperti Rebekah yang menggunakan jilbab dari etnik mesopotamia, di mana jilbab memang menjadi pakaian adatnya. Jilbab semula bagian dari tradisi Mesopotamia-Persia, dan pemisahan laki-laki dan perempuan merupakan tradisi Hellinistik-Bizantium. Jilbab juga pernah menjadi wacana dalam Code Bilalama (3000 SM) berlanjut di dalam Code Hammurabi (2000 SM) dan Code Asyiria (1500 SM). Ketentuan penggunaan jilbab sudah dikenal di beberapa kota tua seperti Mesopotamia, Babilonia dan Asyiria. Yang kemudian menembus sampai pada daerah jazirah Arab seperti Damaskus dan Baghdad. ${ }^{23}$

Institusional jilbab semakin mengkristal metika dunia Islam bersentuhan dengan peradaban Hellenisme dan Persia di kedua kota penting tersebut. ketika perang antara Romawi-Byzantium dan Persia berlangsung, rute perdagangan antarpulau mengalami perubahan untuk menghindari akibat buruk wilayah peperangan. Di beberapa pesisir jazirah Arab tiba-tiba menjadi kota penting sebagai wilayah transit perdagangan. Globalisasi peradaban secara besar-besaran terjadi di masa ini. kultur Hellenisme-Byzantium dan Mesopotamia-Sasania ikut menyentuh wilayah Arab yang tadinya merupakan geokultural tersendiri. ${ }^{24}$ Pada periode ini perempuan terhormat harus menggunakan jilbab di ruang publik.

${ }^{21}$ Moh Toyyib, "Kajian Tafsir Al-Quran Surah Al-Ahzab Ayat 59 (Studi Komparatif Tafsir AlMisbah Dan Tafsir-Tafsir Terdahulu)," Al-Ibrah Vol. 3 No. (2018): 75.

${ }^{22}$ Nasaruddin Umar, Ketika Fikih Membela Perempuan (Jakarta: PT Elex Media Komputindo, 2014), 40 .

23 Umar, 42.

24 Umar, 43. 
Pakaian penutup kepala bagi perempuan di Indonesia, semula lebih umum dibandingkan dengan kerudung. Baru pada permulaan tahun 1980-an menjadi populer dengan istilah jilbab. Jilbab di Indonesia bukan lagi fenomena kelompok sosial tertentu, tetapi sudah menjadi lapisan masyarakat. Maraknya penggunaan jilbab dalam masyarakat sekarang, dianggap sebagai sesuatu hal yang wajar, tidak perlu dikonotasikan dengan sesuatu yang bersifat ideologis. Karena jilbab sebagai pakaian penutup aurat yang telah menjadi bagian tak terpisahkan dengan ajaran Islam yang dianut sebagian besar masyarakat bangsa Indonesia. ${ }^{25}$

Jibab sebagai fenomenan telah dipandang sebagai sebuah eleman bahan pakaian yang hampir secara eksklusif dikaitkan dengan masalah gender, didistorsi oleh catatan etnosentris, atau dikaji dari perspektif kajian wanita saja. Dsengan pendekatan etnosentris dan kajian wanita, jilbab di Timur Tengah dipandang sebagai unsur dari rangkaian ideologis antara praktik dan lembaga yang membentuk jalinan kompleks jilbab-harem-budak-pemingitan-poligami. Jalinan secara kompleks itu dihadirkan sebagai kenyataan yang telah ada sejak ribuan tahun silam. ${ }^{26}$

Dari perspektif feminis, kumpulan lembaga kompleks ini dipandang sebagai penyebab langsung atau ekspresi dari penindasan wanita dari zaman ke zaman. Feminis yang berideologi Barat (baik di Barat maupun di Timur) telah mendominasi wacana jilbab, memandangnya sebagai aspek patriarki serta tanda keterbelakangan, subordinasi, dan penindasan terhadp wanita. Pendekatan unidimensional ini mendangkalkan kejian tentang jilbab menjadi sebuah analisis berkonteks tunggal serta menimbulkan distorsi dalam memandang fenomena kultural yang kompleks. ${ }^{27}$

Dalam bahasa Inggris, istilah veil bisa dipakai untuk merujuk pada penutup tradisional kapala, wajah (mata, hidung, atau mulut), atau tubuh wanita di Timur Tengah dan Asia Selatan. Sebagai kata benda, veil berasal dari kata latin vela, bentuk jamak dari velum. Makna leksikal yang dikandung kata ini adalah "penutup", dalam arti "menutupi" atau "menyembunyikan atau menyaarkan." Sebagai kata benda, kata ini digunakan untuk empat ungkapan: 1. Kain panjang yang dipakai wanita untuk menutup kapala, bahu dan kadang-kadang muka, 2. Rajutan panjang yang ditempelkan pada topi atau tutup kepala wanita yang digunakan untuk memperindah atau melindungi kepala dan wajah, 3. Bagian tutup kepala biarawati yang melingkari wajah terus ke bawah sampai menutupi bahu, 4. Secarik tekstil tipis yang digantung untuk memisahkan atau menyembunyikan sesuatu yang ada dibaliknya. ${ }^{28}$

\section{Kata Khimar dalam QS. an-Nur [24]: 31}

\section{Umar, 43.}

${ }^{26}$ Fadwa El Guindi, Abu Ja'far Muhammad Bin Jarir Tafsir at-Thabari, Terj. Ahsan Askan, jilid 19 (Jakarta: PT Serambi Ilmu Semesta, 2005), 25.

27 El Guindi, 26.

${ }^{28}$ El Guindi, 30. 


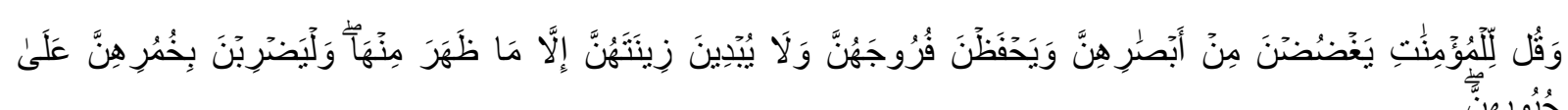

31. Katakanlah kepada wanita yang beriman: "Hendaklah mereka menahan pandangannya, dan kemaluannya, dan janganlah mereka menampakkan perhiasannya, kecuali yang (biasa) nampak dari padanya. Dan hendaklah mereka menutupkan kain kudung kedadanya.... (anNur: 31).

Ayat khimar turun untuk menanggapi model pakaian perempuan yang menggunakan penutup kepala (muqani') tetapi tidak menjangkau bagian dada, sehingga bagian dada sehingga bagian dada dan leher tetap kelihatan. Menurut Muhammad Sa'id Al-Asymawi, QS. an-Nur [24]: 31 turun untuk memberikan perbedaan antara perempuan mukmin dan perempuan selainnya, tidak dimaksudkan untuk menjadi format abadi (yuradu fihi wadl'u at-tamyiz, wa laisa hukman muabbadan). ${ }^{29}$

Lafad khumur merupakan bentuk jamak dari khimar yang bermakna agar menutupi rambut, leher dan anting-anting mereka. Ibnu Waki' menceritakan kepada kami. Ia bekata: Zaid bin Hubaib menceritakan kepadaku dari Ibrahim bin Nafi', ia berkata: Al Hasan bin Muslim bin Yanaq dari Shafiyah binti Syaibah, dari Aisyah, ia berkata, "ketika turun ayat Dan hendaklah mereka menutupkan kain kudung ke dadanya, mereka menyobek kain mantel hingga ke sisi samping dan difungsikan sebagai kerudung. ${ }^{30}$ Yunus menceritakan kepadaku, ia berkata: Ibnu Wahab memeberitahukan kepada kami, ia berkata: Qurrah bin Abdurrahman memberitahukan kepadaku dari Ibnu Syihab dari Urwah, dari Aisyah. Istri Nabi SAW, dia berkata, "Semoga Allah merahmati wanita-wanita kaum Muhajirin yang pertama. Ketika ayat ini diturunkan, Dan hendaklah mereka menutupkan kain kudung ke dadanya, mereka kemudian menyobek kain mereka yang tebal, lalu menggunakannya sebagai kerudung."31

Al Judai menkelaskan bahwa khimar adalah penutup kepala baik berupa kain panjang yang juga menutupi dada ataupun kain pendek yang hanya menutupi rambut ataukah topi yang dikenakan. Dalam pengetian ini, menurut Al Judai khimar tidak hanya terbatas pada kerudung saja akan tetapi seluruh penutup kepala dengan bentuk apapun. ${ }^{32}$ Khimar adalah sesuatu yang digunakan oleh wanita untuk menutupi kepalanya, seperti jilbab. Jadi, jika dia diperintahkan untuk menggambar khimar di atas jaibnya maka dia diperintahkan untuk menutupi wajahnya, baik karena kebutuhan atau karena analogi, karena jika wajib untuk menutupi dada dan leher, maka jelas lebih penting untuk menutupi wajah, karena itu adalah tempat keindahan dan godaan. Maka dari itu menutup wajah lebih utama karena kecantikan

${ }^{29}$ Umar, Ketika Fikih Membela Perempuan, 43.

${ }^{30}$ El Guindi, Abu Ja'far Muhammad Bin Jarir Tafsir at-Thabari, Terj. Ahsan Askan, 110.

31 El Guindi, 110.

32 Theodor Gabriel, Islam and the Veil: Theoretical and Regional Context (Blommsbury Publishing, n.d.). 
pada dasarnya lahir dari wajah yang terlihat. ${ }^{33}$ Jika dilihat tafsir ini menjadi sebuah kontroversi jika diberlakukan di Indonesia, karena negara ini tidak hanya satu agama dan Islam sendiripun tidak hanya satu pemahaman.

Dalam buku lain dijelaskan bahwa khimar yaitu salah satu bentuk dari kerudung yang menutup kepala dan memanjang ke seluruh tubuh (mirip dengan baju tanpa lengan yang dikenakan oleh para biarawati Katolik dan sangat popular dengan mereka jama'ah Masjid. ${ }^{34}$ Ada beberapa penulis yang juga mengartikan khimar adalah pakaian atas atau penutup kepala yang kemudian diperintahkan untuk menutup leher dan menjulur hingga menutupi dada seorang perempuan dari belakang maupun belakang (termasuk menutupi tulang selangka). Khimar pemakaiannya tidak diikatkan ke leher seperti kerudung. Sebab jika dilakukan maka akan memperjelas bentuk lekukan dada dari seorang perempuan. Khimar harus dipakai menjulur ke bawah dari kepala sampai menutupi dada. Sehingga jika menyamakan antara kerudung dan khimar adalah sebuah kekeliruan karena keduanya mempunyai perbedaan yang signifikan. ${ }^{35}$

Dengan demikian khimar adalah salah satu jenis dari kelengkapan berpakaian muslim saja atau bagian dari jenis kelengkapan hijab saja. Jikalau hijab adalah menutup semua aurat sebagai bentuk tata cara berpakaian muslimah, maka jilbab dan khimar merupakan salah satu jenis contohnya. Maka dari itu keduanya berbeda penggunaannya. ${ }^{36}$ Ada pula yang membedakan khimar dan jilbab dengan jilbab lebih diartikan pada jubah sedangkan khimar ke kain atau selendang. ${ }^{37}$ Khimar adalah penutup kepala yang kecil sedagkan jilbab adalah penutup kepala yang lebar. Oleh karenanya, tidak mungkin mengartikan penutup (kepala) yang kecil sedangkan jilbab yaitu penutup kepala yang besar. ${ }^{38}$

\section{Kajian Maghza (Signifikansi)}

Setelah menjelaskan tinjauan aspek linguistik dan aspek historis kontekstual turunnya ayar QS al-Ahzab: 59 dan an-Nur: 31, maka kemudian dapat dilacak sisi maghza sebagai kata kunci dari pesan yang menjadi substansi dan signifikansi utama yang ingin disampaikan oleh Allah melalui kedua ayat tersebut. Kedua ayat ini menjelaskan tentang aurat perempuan yang harus tertutup sampai adanya legitimasi akan kewajiban mengenakan kerudung bagi para muslimah. Sebenarnya kedua ayat ini jika melihat baik dari segi linguistik maupun asbaab al nuzulnya, kedua ayat ini tidak ada yang mewajibkan perempuan untuk memakai kerudung (jilbab). Sebenarnya jika melihat asal kata dari jilbab dan khimar, keduanya mempunyai

33 Shaikh Muhmmad bin Salih Al Uthaimeen, Woman's Hijab, ed. Darussalam Publisher, $2014,5$.

34 Saba Mahmood, Politics of Piety: The Islamic Revival and the Feminist Subject (UK: Princeton University Press, 2005), 41.

35 Raodatul Jannah, Sudah Benarkah Kita Berjilbab? (Bekasi: Guepedia, 2014), 21-22.

36 Jannah, 22.

37 Nancy E Snow, Cultivating Virtue: Perspectives from Philosophy, Theology, and Psychology, Philpapers (OUP USA, 2015).

38 Murtadha Muthahari, Wanita E Hijab (Jakarta: Lentera, 2000), 167. 
perbedaan yang sangat signifikan meskipun sekarang ini terlebih di Indonesia menyamakan keduanya dengan makna kerudung.

Dalam QS. 24:31 ataupun QS. 33: 59 lebih baik dipahami sebagai ayat yang menjelaskan mengenai fungsi menutup aurat bagi perempuan dibandingkan hanya membahas mengenai batasan-batasan aurat bagi para perempuan. ${ }^{39}$ Dengan begitu penutup aurat bagi perempuan tidak lagi dimaknai sebagai sebuah model atau fashion namun lebih kepada kebiasaan dan dilihat sebagai moral dalam cara berpakaian bagi perempuan. ${ }^{40}$

Kedua ayat ini tidak kemudian hanya diperdebatkan dalam masalah batasan aurat mana sajakah yang harus ditutupi. Namun melihat diturunkannya kedua ayat ini dilatarbelakangi dengan peristiwa yang berbeda maka akan melahirkan sebuah makna yang berbeda pula. QS an-Nur dijelaskan bahwa ayat ini diturunkan ketika banyaknya perempuan yang masih mempelihatkan auratnya di depan laki-laki dan mereka merasa terganggu dengan hal itu. Kemudian QS al-Ahzab: 59 dijelaskan bahwa ayat ini diturunkan untuk membedakan antara perempuan merdeka dan budak. Bagaimana dengan keadaan sekarang ini?.

Indonesia dengan berbagai macam suku dan agamanya, dengan toleransi dan keinginan mewujudkan keadaan yang setara antara laki-laki dan perempuan dalam hal posisi gendernya, maka ayat ini tidak kemudian hanya dipahami dengan menutup aurat seperti apa yang telah dijelaskan. Namun dapat ditarik pada keadaan yang lebih tepat. Kata jalaba dan khamara yang mempunyai arti penutup tidak hanya dimaknai sebagai alat untuk menutup kepala saja namun dapat pula dimaknai dengan menutup segala sesuatu yang berhubungan dengan aurat perempuan yang tidak selalu dikaitkan dengan fisik saja.

Maksud menutup aurat ini sebenarnya tidak hanya ditujukan kepada perempuan. Melihat dari asbaab al nuzulnya, ayat ini diturunkan di kawasan yang menganggap bahwa perempuan adalah magnet untuk melakukan kekerasan atau pelecehan seksual. Berbeda dengan hal ersebut, Indonesia menempatkan laki-laki dan perempuan sebagai magnet adanya tindak kekerasan. Keduanya bisa menjadi subjek maupun objek. Maka dari itu sebenarnya memperbaiki moral atau menutup aurat non fisik menjadi tugas bersama. Tidak hanya tugas perempuan untuk selalu menjaga pandangan ataupun hawa nafsu namun juga tugas perempuan.

\section{Central message of Qs. 33: 59 dan 24: 31 dalam Pemahaman Kesetaraan Gender}

Berdasarkan kajian di atas, penulis menyimpulkan pemahaman secara kontekstual dengan menggunakan pendekatan ma'na cum maghza dalam beberapa poin berikut:

Pemaknaan baru mengenai kata jilbab dan khimar yang tidak hanya berhenti pada pemaknaan penutup aurat secara fisik namun juga menutup aurat yang dilihat

${ }^{39}$ Ziauddin Sardar, Reading the Quran: Contemporary Relevance of the Sacred Text of Islam (New York: Oxford University Press, 2010), 47.

${ }^{40}$ Sardar, 48. 
secara non fisik. Kewajiban menutup aurat non fisik tidak hanya dibebankan kepada perempuan namun juga kepada laki-laki. Hal ini dapat dilihat dari sebab turunnya ayat yang tidak terjadi di negara Indonesia. Maka dari itu hal ini membuktikan bahwasanya antara laki-laki dan perempuan sama-sama dapat ditempatkan sebagai subjek seksualitas. Menurut musdah mulia, seksualitas adalah sebuah proses sosial yang menciptakan dan mengarahkan hasrat atau berahi. Seksualitas ${ }^{41}$ adalah sesuatu yang dikonstuksikan secara sosial (to socially constructed expression of eroctic desire), sesuatu yang bersifat positif. Seksualitas perempuan adalah suatu hal yang independen dan menjadi hak perempuan sepenuhnya. ${ }^{42}$ Kenikmatan seksual bukan hanya untuk kaum laki-laki dengan anggapan bahwasanya perempuan/istri hanya untuk melayani keinginan sesksual laki-laki/suami. Seks bagi perempuan juga tidak sekadar sebuah kewajiban tetapi juga sebagai hak untuk memperoleh kenikmatan atau menolak manakala ia tidak siap untuk hubungan tersebut sehingga tidak harus melakukan seks secara terpaksa. ${ }^{43}$

Moralitas perempuan tidak dapat dinilai dari seksualitasnya dan tidak dapat dinilai dari sudut pandang laki-laki. ia memiliki keunikan sendiri sebagaimana individu sebagaimana halnya laki-laki. Akan tetapi ideologi patriatki memiliki peran mengkonstruksi citra publik tentang tubuh perempuan. Konstuksi tubuh perempuan telah merasuk dengan sedemikian rupa dalam benak masyarakat. Tidak heran jika sudut pandang laki-laki menjadi standar nilai dalam memandang tubuh perempuan dan yang menjadi acuan dalam menilai tubuh perempuan. ${ }^{44}$ Penilaian moralitas yang tidak adil ini membawa kepada lahirnya berbagai stereotip mengenai tubuh

41 Seksualitas adalah sesuatu yang instingtif, intrinsik dan fitrah bagi semua jenis kelamin, bukan hanya milik laki-laki, tetapi juga perempuan dengan kadar yang relatif sama. Seksualitas adalah sentral dalam diri manusia. Akan tetapi sepanjang sejarah peradaban manusia, seksualitas perempuan selalu mengalami reduksi makna secara besar-besaran. Seksualitas perempuan ditempatkan dalam posisi yang direndahkan, dieksploitasi untuk kesenangan laki-laki. Ini adalah wajah dari kebudayaan patriarkhi yang paradoks yang terus dipertahankan sampai hari ini dengan beragam cara oleh berbagai kepentingan. Kepentingan diri, politik, sosial, budaya dan lain-lain. Di banyak komunitas dunia, termasuk di dunia muslim, seksualitas perempuan diperbincangkan secara ambigu. Ia bisa dibicarakan dengan penuh apresiasi dan diagungkan tetapi dalam waktu yang sama juga sangat tertutup, tabu dan konservatif. Seksualitas dirayakan dengan nuansa-nuansa kemegahan dan penuh nuansa-nuansa sakralitas. Ini misalnya muncul dalam upacara perkawinan. Perkawinan adalah sebuah mekanisme yang disakralkan untuk wahana kebebasan manusia mengaktualisasikan hasrat-hasrat seksualnya. Perempuan dalam upacara ini ditampilkan secara terbuka dan dipersiapkan untuk tampil dengan performance yang begitu elok, penuh pesona dan potensial menarik hasrat libido laki-laki. Tetapi pada momen yang lain tubuh perempuan dan keelokannya seringkali tak boleh diekspresikan di ruang publik, hasrat-hasrat biologisnya dibatasi dan dikendalikan oleh orang lain. lihat Husein Muhammad, "Islam Dan Seksualitas," n.d., diakses Minggu, 28 oktober 2019 pukul 22:50 WIB, https://lakilakibaru.or.id/islam-dan-seksualitas/.

42 Siti Musdah Mulia, "Allah Hanya Melihat Takwa, Bukan Orientasi Seksual Manusia," n.d., Minggu, 28 Oktober 2019 pukul 22:30 WIB, https://www.jurnalperempuan.org/tokoh-feminis/sitimusdah-mulia-allah-hanya-melihat-takwa-bukan-orientasi-seksual-manusia.

${ }^{43}$ Sri Suhandjati Sukri, Bias Jender Dalam Penafsiran Al-Qur'an (Yogyakarta: Gama Media, 2002), 26.

${ }^{44}$ Mulia, “Allah Hanya Melihat Takwa, Bukan Orientasi Seksual Manusia," Minggu, 28 Oktober 2019 pukul 22:30 WIB. 
perempuan yang sering dianggap sebagai penggoda, perusak kesucian laki-laki, pembawa bencana dan sejumlah stereotip lainnya.

Perlu ditegaskan kembali bahwasanya ketidakadilan gender pada perempuan tidak hanya berupa subordinasi keberadaan perempuan, akan tetapi juga muncul dalam bentuk stereotip (pelabelan negatif) yang diletakkan pada diri perempuan. Misalnya stereotip tentang perempuan sebagai makhluk penggoda, sehingga sering terdengar cibiran: "hati-hati terhadap perempuan karena godaannya jauh lebih dahsyat dari pada godaan syetan. Berbagai manifestasi ketidakadilan gender tersebut saling terkait satu sama lain. Wujud ketidakadilan tersebut terisolasi dalam masyarakat, dalam diri laki-laki dan perempuan yang lama kelamaan dianggap sebagai sesuatu yang wajar atau taken for granted atau sudah seharusnya demikian atau menjadi 'kodrat'. Implikasi dari hal tersebut adalah sulit dibedakannya peranperan gender antara yang kodrat dan mana yang merupakan hasil konstruksi. ${ }^{45}$

Merujuk pada konteks pada masa kini, bahwa tubuh perempuan tak lagi dibatasi oleh pemahaman bias gender. Perempuan memiliki kemerdekaan atas tubuhnya sendiri. Tubuh perempuan bukanlah sebuah sumber dosa dan keonaran sebagaimana yang sering diungkapkan masyarakat, justru adanya pikiran yang demikian menjadi masalah baru. Nilai-nilai moral yang telah dideskripsikan oleh laki-laki ini menjadi timpang karena dilihat dari sudut laki-laki. laki-laki dan perempuan seharusnya ditempatkan pada kedudukan yang sama, termasuk dalam hal pemenuhan kebutuhan biologis.

\section{KESIMPULAN}

Kata jilbab dan khimar sampai sekarang ini masih seringkali dimaknai dengan penutup kepala yang berimbas pada pemahaman wajibnya menggunakan jilbab atau yang disebut khimar bagi perempuan Muslimah. Dengan melihat pemaknaan kata jilbab dan khimar dengan menggunakan pendekatan ma'na cum maghza maka akan melajirkan pemaknaan baru mengenai kata jilbab dan khimar yang tidak hanya berhenti pada pemaknaan penutup aurat secara fisik namun juga menutup aurat yang dilihat secara non fisik. Kewajiban menutup aurat non fisik tidak hanya dibebankan kepada perempuan namun juga kepada laki-laki. Hal ini dapat dilihat dari sebab turunnya ayat yang tidak terjadi di negara Indonesia. Maka dari itu hal ini membuktikan bahwasanya antara laki-laki dan perempuan sama-sama dapat ditempatkan sebagai subjek seksualitas.

45 Musdah Mulia, Muslimah Reformis: Perempuan Pembaru Keagamaan (Bandung: Mizan, 2004), 219-222. 


\section{DAFTAR RUJUKAN}

Abdullah. "Metodologi Penafsiran Kontemporer (Telaah Pemikiran Sahiron Syamsuddin Tahun 1990-2013)." Fakultas Ushuluddin dan Pemikiran Islam UIN Sunan Kalijaga Yogyakarta, 2013.

Al-Suyuti, Jalaluddin. Lubab Al-Nuqul Fi Asbab Al-Nuzul. Beirut: Muassasat al-Kutub al-Tsaqafiyyah, 2002.

Amir, Abdul Muiz. “Dinamika Dan Terapan Metodologi Tafsir Kontekstual (Kajian Hermenutika Ma'na-Cum-Maghza Terhadap Penafsiran QS Al-Ma'un/107)." Al Izzah: Jurnal Hasil-Hasil Penelitian Vol. 14 No (2019).

Gabriel, Theodor. Islam and the Veil: Theoretical and Regional Context. Blommsbury Publishing, n.d.

Guindi, Fadwa El. Abu Ja'far Muhammad Bin Jarir Tafsir at-Thabari, Terj. Ahsan Askan. Jilid 19. Jakarta: PT Serambi Ilmu Semesta, 2005.

Jannah, Raodatul. Sudah Benarkah Kita Berjilbab? Bekasi: Guepedia, 2014.

Mahmood, Saba. Politics of Piety: The Islamic Revival and the Feminist Subject. UK: Princeton University Press, 2005.

Muhammad, Husein. “Islam Dan Seksualitas,” n.d. https:/ /lakilakibaru.or.id/islamdan-seksualitas/.

Mulia, Musdah. Muslimah Reformis: Perempuan Pembaru Keagamaan. Bandung: Mizan, 2004.

Mulia, Siti Musdah. "Allah Hanya Melihat Takwa, Bukan Orientasi Seksual Manusia," n.d. https:/ / www.jurnalperempuan.org/tokoh-feminis/siti-musdahmulia-allah-hanya-melihat-takwa-bukan-orientasi-seksual-manusia.

Muthahari, Murtadha. Wanita \& Hijab. Jakarta: Lentera, 2000.

Ramadhani, Eveline. “Jilbab Sebagai Representasi Simbolik Mahasiswi Muslim Di Universitas Indonesia." Masyarakat Jurnal Sosiologi Vol. 27 No (2017).

Sardar, Ziauddin. Reading the Quran: Contemporary Relevance of the Sacred Text of Islam. New York: Oxford University Press, 2010.

Snow, Nancy E. Cultivating Virtue: Perspectives from Philosophy, Theology, and Psychology. Philpapers. OUP USA, 2015.

Sukri, Sri Suhandjati. Bias Jender Dalam Penafsiran Al-Qur'an. Yogyakarta: Gama Media, 2002.

Syamsuddin, Sahiron. Hermeneutika Dan Pengembangan Ulumul Qur'an. Yogyakarta: Pesantren Nawesea Press, 2009.

- - - "Ma'na-Cum-Maghza Approach to The Quran: Interpretation of Q. 5:51." Education and Humanities Research Vol. 137 (2017).

- - - "Tipologi Dan Proyeksi Penafsiran Kontemporer Terhadap Al-Qur'an." AlQur'an Dan Hadis Vol. 8 No. (2007).

Toyyib, Moh. "Kajian Tafsir Al-Quran Surah Al-Ahzab Ayat 59 (Studi Komparatif Tafsir Al-Misbah Dan Tafsir-Tafsir Terdahulu)." Al-Ibrah Vol. 3 No. (2018). 
Umar, Nasaruddin. Ketika Fikih Membela Perempuan. Jakarta: PT Elex Media Komputindo, 2014.

Uthaimeen, Shaikh Muhmmad bin Salih Al. Woman's Hijab. Edited by Darussalam Publisher, 2014.

Wahidi, Al. Asbab Al-Nuzul. Beirut: Dar al-Kutub, 1991.

Yulaikhah, Safitri. "Jilbab Antara Kesalehan Dan Fenomena Sosial." Jurnal Ilmu Dakwah Vol. 36 No (2016). 